\title{
COMPLEMENTARY METHODS TO MITIGATE THE MISINTERPRETATION OF RESULTS DUE TO COLLINEARITY IN INTERNATIONAL BUSINESS RESEARCH
}

\author{
Diogenes de Souza Bido, Antonio Carlos de Oliveira Barroso \& ${ }^{1}$ Eric David Cohen \\ Universidade Presbiteriana Mackenzie - M, São Paulo, (Brasil) \\ Instituto de Pesquisas Energéticas e Nucleares - IPEN, São Paulo, (Brasil) \\ Universidade Estadual de Campinas - UNICAMP, Campinas, São Paulo, (Brasil)
}

\begin{tabular}{l}
\hline ARTICLE DETAILS \\
\hline Article history: \\
Received: 19 january 2021 \\
Accepted: 03 july 2021 \\
Available online october: 25 th 2021 \\
Double Blind Review System \\
Scientific Editor \\
Ilan Avrichir \\
\hline Keywords \\
Structural equation modeling \\
Multicollinearity \\
International Business
\end{tabular}

\section{INTRODUCTION}

Nowadays, understanding the challenges imposed by a context of an ever-changing global business environment has received increasing attention from decision-makers and International Business scholars. In this paper, we develop an investigation of a complementary methodology to help address uncertainty in International Business, in line with our quest to construct knowledge that is valid and relevant, thus providing ample opportunities for development in this field of knowledge.

In that regard, researchers in International Business use analytical techniques to demonstrate the effect of independent variables on a dependent variable, by proposing hypotheses based on concepts and theories. Advanced methods are used for that such as structural equation modelling (SEM), covariance-based models, regression analysis and other analytical techniques.

Structural Equation Modelling is subdivided into different classes in terms of modeling purposes: CBSEM (covariance-based SEM) and PLS-SEM (Hair et al., 2016). CB-SEM estimates model parameters and attempts to reproduce, empirically, the actual covariance matrix. On the other hand, PLS-SEM is the analytical technique of choice for exploratory research. We refer the interested reader to authors such as Hair et al. (2016) and Ringle and Sarstedt (2020) for a discussion of the differences between CB-SEM and PLS-SEM.

Structural models are used to empirically express abstract concepts, test hypotheses based on inductive or deductive reasoning, and build knowledge that relates to the International Business

\footnotetext{
${ }^{1}$ Contact of the author E-mail: EricDCohen@gmail.com
} 
perspective in themes as diverse as changes in global contexts, global value chains, foreign direct investment, patterns in the internationalization and regionalization, all of which affect business strategies and determine multinational corporations' competitiveness.

Partial least squares structural equation modeling (PLS-SEM) has been increasingly used to estimate predictors with latent variables and their relationships. It is a popular method, useful when formative constructs are included in the structural model (Hair Jr., Hult, Ringle and Sarstedt, 2016).

Structural models typically examine the covariance or correlation between variables. In that regard, collinearity is defined as the correlation that exists between two independent variables in regression models, whereas multicollinearity is defined as the relationship of an independent variable with all other variables. The higher the multicollinearity, the larger will be the variance portion of the independent variable that is explained by some other variable (Gujarati, 2003; Hair et al. , 2010).

Specifically, as posited by Cohen et al. (2003, p. 425),

When a researcher is only interested in predicting $\mathrm{Y}$ or the value of $\mathrm{R}^{2}$, multicollinearity has little effect and no corrective action is required. However, in research that tests a substantive theory in which the researcher is interested in the value of every [predictor], high values of multicollinearity present a potentially serious problem.

Our main methodological objective focuses on the effects of multicollinearity when testing International Business theories and concepts, as well as the prescription of remedies to mitigate it. Hence, our study contributes to the solution of a highly relevant problem, from the theoretical and methodological perspective - namely, addressing the risks posed by a possible loss of validity of structural models as I.B. theories are built. Our main goal is to ensure that empirical results are sound and coherent, and that multicollinearity is kept in check.

Since collinearity renders models invalid, the article bears great relevance to help guide scholars in the development of robust, relevant and reliable empirical research. Hence, our aim is to arrange responses that address this empirical issue, as well as to demonstrate the appropriate use of techniques and complementary methodological practices in International Business research.

Seno-Alday (2010) posits that International Business is a relatively young field, compared to other management areas. In addition, I.B. foundations have changed over time, challenged by continuous shifts in the firm's internationalization settings; for instance, the research agenda in the post-WWII period focused on trade and foreign direct investment, which subsequently shifted to multinational firms' management, globalization, the nature of the interaction between different national environments, and formal or informal institutional environments, to name a few.

Along the same line, authors such as Buckley (2002) and Seno-Alday (2010) posit that this reinforces the need to use appropriate methodological approaches to help address the gaps of knowledge that which result from I.B.'s changing nature, in light of the field's broad context of theory building.

To be sure, since the I.B. literature centers on existing knowledge, this prompts for extant research that addresses the expansion, modification, and further development of its state of the art. Fittingly, much of the research is founded on theoretical explanations; incidentally, it is not uncommon for concepts to be borrowed from other disciplines (such as psychology, social sciences and economics). This means that international business and marketing are becoming an increasingly complex field of knowledge, whereby theories attempt to explain the fluidity of its environment.

Importantly, the pertinence of this line of investigation for International Business is corroborated by extant research, as evidenced as Richter, Sinkovics, Ringle and Schlägel's (2016) work. The authors published a highly relevant article in the focused issue of the Management International Review Journal. They note, at its inception, that multicollinearity in regression models is a well-known issue. Still, since PLS structural models use ordinary least squares regression, it follows that multicollinearity must be recognized as an important hurdle for the development of theories in the I.B. field and empirical testing.

DuBois and Reeb (2000) present a list of core and prestigious I.B. journals, reproduced in table 1. 
Table 1 - International Business core journals - ranking

\begin{tabular}{|c|c|}
\hline Rank & journal name \\
\hline 1 & Journal of International Business Studies \\
\hline 2 & Management International Review \\
\hline 3 & Journal of World Business \\
\hline 4 & International Marketing Review \\
\hline 5 & International Business Review \\
\hline 6 & Journal of International Marketing \\
\hline 7 & International Studies of Management and Organization \\
\hline 8 & Advances in International Marketing \\
\hline 9 & Advances in International Comparative Management \\
\hline 10 & International Journal of Research in Marketing \\
\hline 11 & Journal of Global Marketing \\
\hline 12 & Multinational Business Review \\
\hline 13 & International Journal of Management \\
\hline 14 & International Management \\
\hline 15 & Journal of International Financial Mgt and Accounting \\
\hline 16 & The International Journal of Accounting \\
\hline 17 & Advances in International Accounting \\
\hline 18 & Global Finance \\
\hline 19 & International Trade Journal \\
\hline 20 & Journal of International Management \\
\hline 21 & Journal of International Consumer Marketing \\
\hline \multirow{9}{*}{22} & Advances in International Banking and Finance \\
\hline & International Journal of Conflict Management \\
\hline & International Journal of Finance \\
\hline & International Review of Strategic Management \\
\hline & Journal of International Finance \\
\hline & Journal of International Marketing and Marketing Research \\
\hline & Journal of Multinational Financial Management \\
\hline & Multinational Finance Journal \\
\hline & Thunderbird International Business Review \\
\hline
\end{tabular}

Source: DuBois and Reeb (2000)

The Academic Journal Guide (2021) ranking criteria was used to demonstrate the lack of multicollinearity concerns in extant I.B. research. AJG lists the top tier academic outlets in terms of the quality of scientific production: the $4 *$ Journals of Distinction are comprised of a reduced number of top-grade publications - in other words, they are recognized world-wide as exemplars of excellence. In turn, journals rated 4 publish some of the most original papers, have high submission and low acceptance rates; journals with rankings 2 and 3 publish original and well executed research, are highly regarded and have excellent metrics with respect to other periodicals. 29 International Business journals with rankings $4^{*}, 4,3$ and 2 comprise our frame of reference.

Following the recommendation by White, Guldiken, Hemphill, He and Khoobdeh (2016), all areas of I.B. were considered. Not surprisingly, articles contain a multiplicity of subject matters and were produced by authors with different research streams, including (but not limited to): the Internationalization Process; Multinationals; Country of Origin; Innovation; Entry Modes; Expatriation; Entrepreneurship; Firm Performance; Strategic Alliances; Resource Configuration; Team Orientation; Human Resource practices; and Cultural Distance, Diversity and Competences.

Based on the premise that the selected Journals are highly regarded and produce relevant, original and well-executed work, 20 articles were selected from: the Journal of International Business Studies $\left(4^{*}\right)$; the Journal of International Management (3); Management International Review (3); and Cross Cultural \& Strategic Management (2). The papers contain the keyword "PLS-SEM" and had structural models with paths leading to some dependent variable, as shown in attachment 1. 
In five papers, the structural coefficients were not significant. Interestingly, in 9 articles the direction of the results (i.e., the sign of the path coefficient) was the opposite of what the authors expected. The remaining articles were analyzed to identify comments regarding the collinearity issue; however, only five papers mentioned it. Furthermore, two papers discussed the nonsignificant predictors and the suppression effect - i.e., the situation where the structural coefficient is negative, but the correlation between variables is positive. Our first conclusion is that extant I.B. research does not sufficiently address the issue, nor does it provide the adequate controls in order to keep it checked.

It is well established knowledge that - since the structural model uses ordinary least squares regression - collinearity is a key issue of concern on the estimation of the predictors, as in regression analysis (Gujarati, 2003; Kennedy, 1998). Grewal, Cote and Baumgartner (2004), Diamantopoulos et al. (2008) and Henseler et al. (2009) corroborate this, and strongly keeping collinearity in check.

According to Henseler et al. (2009), the estimation of structural models is not sufficiently robust when there is collinearity. Still, the evaluation of its effects has not been operated in a consistent manner, and there is a lack of understanding which leads to flawed conclusions about the magnitude of the structural and measurement relationships. Richter, Sinkovics, Ringle and Schlägel (2016) corroborate this, by stressing the importance of understanding weak effect sizes and report the item's importance, weights and significance, and posit that the Variance Inflation Factor (VIF) and condition index are good metrics to be followed by researchers.

As an emblematic example, the predicament of multicollinearity is illustrated by Tenenhaus et al. (2005, p. 180), in which the predictor of two variables (expectation and satisfaction) was not significant (even though correlation was 0.48 ; bear in mind this would be considered a strong effect per Cohen's (1988) criterion). In all likelihood, coefficients were not significant because of other some predictors strongly correlated with the dependent variables. We analyzed data from the SmartPLS website (Ringle,
Wende and Becker, 2020) to understand it, and multicollinearity was found to be larger than the indicators (2.84 vs. 2.10).

Lastly, our choice of the Review of International Business Journal as a research outlet is predicated on its editorial focus, which not only stimulates work, in areas such as the internationalization of companies, multinational company strategy, subsidiary and corporate relationships to name a few of the relevant themes, but, more importantly, it seeks publications of research and reflections in the field that are transversal to the different areas of management.

\section{RESEARCH DEVELOPMENT}

If the primary objective is to define hypotheses, the I.B. researcher usually begins with a fairly broad spectrum of potential explanations for the phenomenon at hand. Subsequently, the focus of assessment is narrowed by using a deductive approach to define relations between observed variables and latent constructs, as well as to identify relevant and dominant effects. In this case, the literature provides conceptual foundations for the development of the hypotheses that can be empirically tested. When a hypothesis is not rejected, the researcher might be confident with regards to the validity of the underlying theory.

Other fields of knowledge, such as family business research, management information systems, marketing and strategic management show a broad and increasing use of PLS-SEM.

Strangely enough, Richter et al. (2016) found that covariance-based SEM is more extensively used than PLS-SEM in I.B. Hence, international business research has not relied much on the PLS-SEM technique, and the authors note that this is a rather unanticipated outcome, given the specifics of the research environment and agenda (see table 2). Incidentally, Richter et al.'s (2016) work was published in a top-ranked outlet - which corroborates the importance of their innovative and relevant work, which links SEM use to I.B. research. 
Table 2: Journals and number of papers using PLS-SEM

\begin{tabular}{|c|c|c|}
\hline Journal & Papers & Authors \\
\hline $\begin{array}{l}\text { International Business } \\
\text { Review }\end{array}$ & 15 & $\begin{array}{l}\text { Inkpen and Birkenshaw (1994), Pullman et al. } \\
\text { (1997), Ellis (2010), Gammelgaard et al. (2012), } \\
\text { Chung et al. (2012), Mallin et al. (2010), Ketkar et } \\
\text { al. (2012), Papadopoulos and Martín (2010), } \\
\text { Khalid and Larimo (2011), Ciabuschi et al. (2012), } \\
\text { Nielsen and Gudergan (2012), Bloemer et al. } \\
\text { (2012), Castro and Roldán (2013), Chung and } \\
\text { Rung (2013) and Lew et al. (2013) }\end{array}$ \\
\hline $\begin{array}{l}\text { International Marketing } \\
\text { Review }\end{array}$ & 4 & $\begin{array}{l}\text { Alpert et al. (2001), Singh et al. (2006), Duque and } \\
\text { Lado (2010) and Sinkovics et al. (2013) }\end{array}$ \\
\hline $\begin{array}{l}\text { Journal of International } \\
\text { Business Studies }\end{array}$ & 7 & $\begin{array}{l}\text { Venaik et al. (2005), Lee et al. (2006), Fey et al. } \\
\text { (2009), Lam et al. (2012), Money and Graham } \\
\text { (1999), Shi et al. (2010) and Schotter and Beamish } \\
\text { (2013) }\end{array}$ \\
\hline $\begin{array}{l}\text { Journal of International } \\
\text { Management }\end{array}$ & 4 & $\begin{array}{l}\text { Teigland and Wasko (2009), Engelen (2010), } \\
\text { Bader and Berg (2013) and Raman et al. (2013) }\end{array}$ \\
\hline Journal of World Business & 8 & $\begin{array}{l}\text { Fang et al. (2012), Acedo and Jones (2007), } \\
\text { Ainuddin et al. (2007), Navarro et al. (2010), } \\
\text { Ciabuschi et al. (2011), García-Villaverde et al. } \\
\text { (2012), Johnson et al. (2013) and Sarstedt et al. } \\
\text { (2013) Management }\end{array}$ \\
\hline International Review & 7 & $\begin{array}{l}\text { Venaik et al. (2004), West and Graham (2004), Li } \\
\text { et al. (2006), Boehe (2010), Ciabuschi et al. (2010), } \\
\text { Swoboda et al. (2012) and Obadia (2013) }\end{array}$ \\
\hline
\end{tabular}

Source: adapted from Richter et al. (2016)

Suitably, Tsui (2007) shows that much of the research in international business attempted to explain problems for which no specific international business theory was available. Along the same line, Dunning (2008) posits that the evaluation of methodological approaches to address the I.B. issues is a priority on the international business agenda. This corroborates the justification of this research, namely: the need to adopt practical guidelines and better choices for the correct use of the analytic technique, as well as offering concrete recommendations in terms of sound methodological practices for I.B. research.

Table 3: PLS-SEM articles in Journals

\begin{tabular}{|l|c|}
\hline International Business Review & 15 \\
\hline International Marketing Review & 4 \\
\hline Journal of International Business Studies & 7 \\
\hline Journal of International Management & 4 \\
\hline Journal of World Business & 8 \\
\hline Management International Review & 7 \\
\hline \multicolumn{2}{|c|}{ Years } \\
\hline $1990-1994$ & 1 \\
\hline $1995-1999$ & 2 \\
\hline $2000-2004$ & 3 \\
\hline $2005-2009$ & 8 \\
\hline $2010-2013$ & 31 \\
\hline Total & 45 \\
\hline
\end{tabular}

Source: adapted from Richter et al. (2016) 
Of the total 45 I.B. papers analyzed in table 3 , only 2 provided an assessment of reliability and validity this accounts for only 5 percent of the papers analyzed by the authors. In addition, they noted that - while reviews that outline PLS-SEM good practices have evolved in various management disciplines such as accounting, management information systems, marketing and operations management - only 8 articles provided an analysis that follows guidelines for multicollinearity, specifically, reporting the Variance Inflation Factor: < 5. None reported tolerance $>0.2$ or condition index $<30$, per Hair et al.'s (2016) recommendations.

The authors posit that PLS-SEM offers increased potential to uncover new causal relationships that are pertinent to I.B. models, since they capture complex patterns and relationships, thus helping develop theory building, focusing on prediction and softmodeling. They concluded that the benefits of PLS-

$r_{12}$

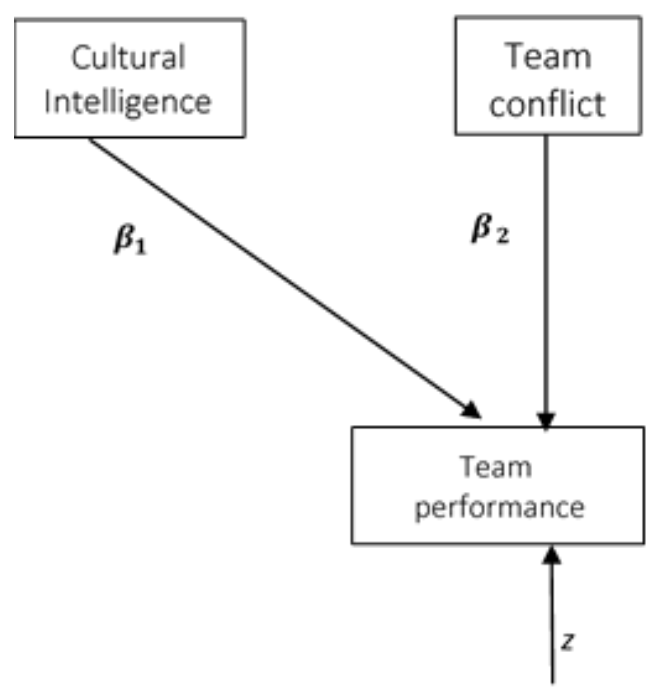

Figure 1: model with two independent variables

Source: Prepared by the authors from Beaujean (2014, p. 25-26).

We analyzed collinearity by inspection of the significance and magnitude of path coefficients. A graph is provided in figure 2 to depict the results $\left(r_{1 Y}\right.$ $=0.30$ and $r_{2 Y}=0.20$ ) and characterize non-significant predictors or VIF values deemed to be important namely,
SEM do not appear to be sufficiently exploited by I.B. scholars.

To demonstrate the multicollinearity effects in predictive models, we initially note that PLS-SEM models are estimated in a single step. The structural model is calculated in an interactive manner using ordinary least squares estimation methods. The estimates for factor loadings and path coefficients may be subject to multicollinearity.

A simplification was made to highlight the results of our simulation. By way of example, consider a simple model with only two independent variables in figure 1. Assuming that the correlations between the independent variables (IV) and the dependent variable (DV) vary between 0.2 and 0.7 , the correlations were manipulated and produced multicollinearity (with VIF ranging from 1 to 11, in increments of 0.01 , yielding fifteen different scenarios and 1001 estimates).

\section{$r_{x y}=$ direct effect + indirect effect \\ $r_{1 y}=$ correlation between cultural intelligence and team performance}

$$
\begin{aligned}
& r_{1 y}=\beta_{1}+\beta_{2} \cdot r_{12} \\
& r_{2 y}=\beta_{2}+\beta_{1} \cdot r_{12} \\
& V I F=\frac{1}{1-r_{12}^{2}} \\
& \beta_{1}=r_{1 y}-\beta_{2} \cdot r_{12} \\
& \beta_{2}=r_{2 y}-\beta_{1} \cdot r_{12} \\
& \text { Substituting [5] in [4] yields: } \\
& \beta_{1}=r_{1 y}-r_{2 y} \cdot r_{12} \\
& \quad 1-r_{12}^{2} \\
& \therefore \beta_{1}=\left(r_{1 y}-r_{2 y} \cdot r_{12}\right) . \text { VIF }
\end{aligned}
$$


VIF where path coefficient is greater than $|1|$.

The scenarios demonstrate that - regardless of the meaning, conceptual or operational definition of the variables - , when IV and DV have high correlation, then the predictor will increase as multicollinearity increases. Conversely, when correlation is low, the predictor will decrease as VIF increases. Note that there is a linear trend with respect to the path coefficient for VIF values greater than 2 .

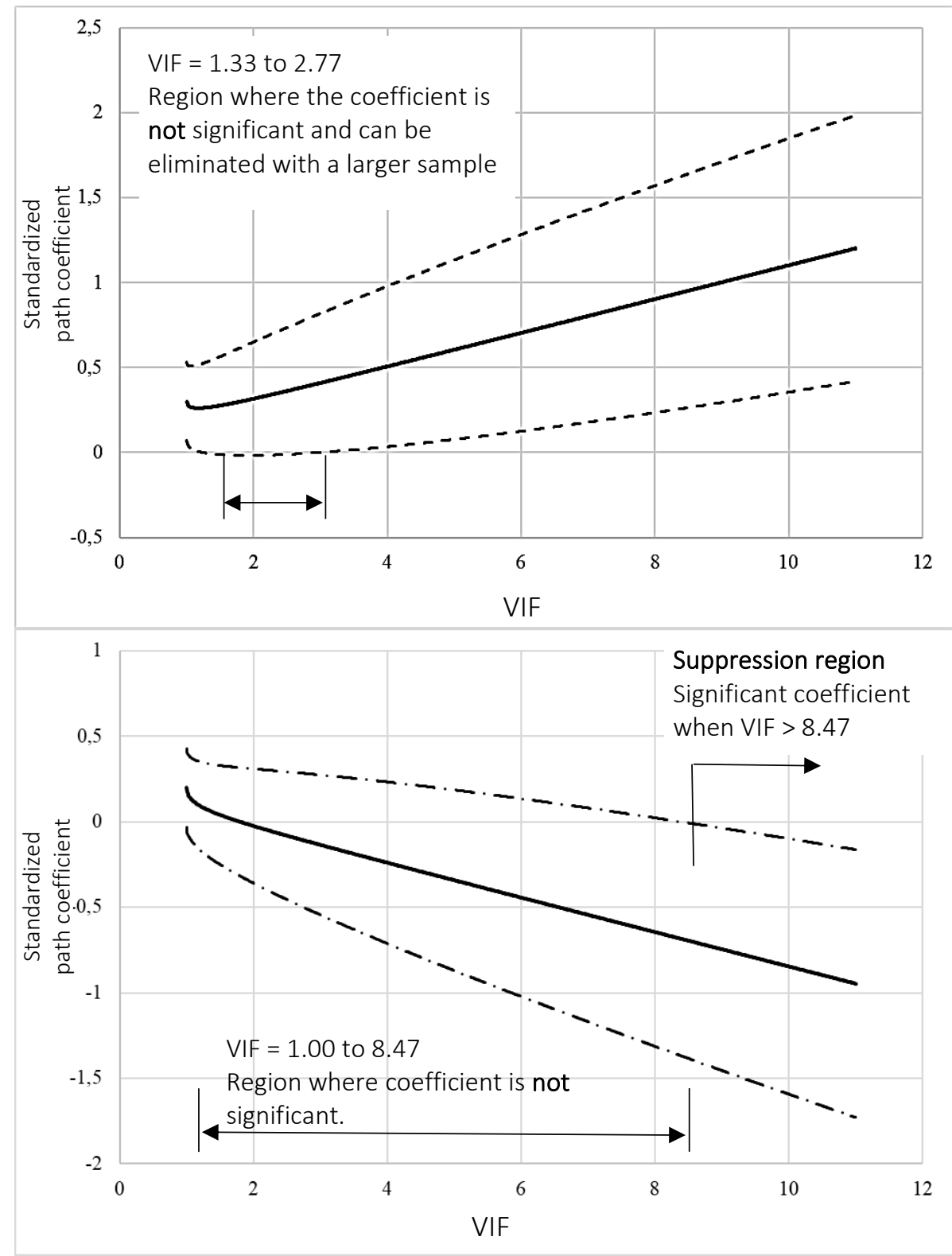

For the independent variable that has the greatest correlation value with the dependent variable,

path coefficient increases as the collinearity (VIF) increases.

For the independent variable that has the lowest correlation with the dependent variable

path coefficient decreases as the collinearity (VIF) increases.

Figure 2: Path coefficients and confidence intervals as a function of multicollinearity Source: research results.

The solid lines represent the mean values, and the dashed lines are the lower and upper limits of the confidence interval $(95 \%$, with $n=68)$. The graph was separated into two halves for better visualization.

Note 1: In this simulation, $r_{1 Y}=0.3$ and $r_{2 Y}=0.2$ were used (scenario 2 from a total of 15 ).
Note 2: We could have adopted different sampling procedures (possibly with larger confidence intervals), but used $\mathrm{N}=68$ cases. This corresponds to the lower sampling requirement for a 5\% significance, statistical power of $80 \%$ and average effect size $\left(f^{2}=\right.$ $0.15)$, according to $G^{*}$ Power 3 software. 
The graphs for the fifteen scenarios provide a simulation of the behavior of predictors as a function of VIF but they are not meant to identify values when the predictors are not significant. To that end, table 4 illustrates the range of VIF that yields non-significant values for each scenario.

Table 4: Effect of collinearity on path coefficients

\begin{tabular}{|c|c|c|c|c|c|}
\hline $\begin{array}{l}\text { Scenario } \\
\text { (Note 1) }\end{array}$ & $\begin{array}{l}\text { Correlations } \\
\text { between } \\
\text { independent and } \\
\text { dependent } \\
\text { variables }\end{array}$ & $\begin{array}{l}\text { VIF interval in which } \\
\text { path coefficients are } \\
\text { not significant at } 5 \% \text { (n } \\
=68)\end{array}$ & $\begin{array}{l}\text { VIF interval in which } \\
\text { path coefficients are } \\
\text { significant and } \\
\text { negative } \\
\text { (suppression) }\end{array}$ & $\begin{array}{l}\text { VIF in which path } \\
\text { coefficient }>|1| \\
r_{12} \text { in which path } \\
\text { coefficient }>|1|\end{array}$ & $\begin{array}{c}\text { VIF when } \\
\text { minimum } \mathrm{R}^{2} \text { is } \\
\text { reached } \\
\text { (redundancy } \\
\text { between } \mathrm{x}_{1} \text { and } \\
\mathrm{X}_{2} \text { ) } \\
\end{array}$ \\
\hline \multirow{2}{*}{1} & 0.2 & $\mathrm{VIF} \geq 1$ & not applicable & not applicable & \multirow[b]{2}{*}{10.76} \\
\hline & 0.21 & $\mathrm{VIF} \geq 1$ & not applicable & not applicable & \\
\hline \multirow{2}{*}{2} & 0.2 & 1.00 thru 8.47 & above 8.47 & $\begin{array}{c}\text { VIF }>11 \\
(r>0.953)\end{array}$ & \multirow{2}{*}{1.8} \\
\hline & 0.3 & 1.33 thru 2.77 & not applicable & $9.03(0.943)$ & \\
\hline \multirow{2}{*}{3} & 0.2 & 1.00 thru 3.12 & above 3.12 & $6.06(0.914)$ & \multirow{2}{*}{1.33} \\
\hline & 0.4 & always significant & not applicable & $4.49(0.882)$ & \\
\hline \multirow{2}{*}{4} & 0.2 & 1.00 thru 2.00 & above 2.00 & $4.24(0.874)$ & \multirow{2}{*}{1.19} \\
\hline & 0.5 & always significant & not applicable & $2.99(0.816)$ & \\
\hline \multirow{2}{*}{5} & 0.2 & 1.01 thru 1.34 & above 1.34 & $2.79(0.801)$ & \multirow{2}{*}{1.09} \\
\hline & 0.7 & always significant & not applicable & $1.77(0.660)$ & \\
\hline \multirow{2}{*}{6} & 0.3 & above 1.08 & not applicable & $\begin{array}{l}\text { not applicable } \\
\text { (note 2) }\end{array}$ & \multirow{2}{*}{$\mathrm{VIF}>11$} \\
\hline & 0.31 & above 1.11 & not applicable & not applicable & \\
\hline \multirow{2}{*}{7} & 0.3 & 1.06 thru 8.87 & above 8.87 & $\mathrm{VIF}>11$ & \multirow{2}{*}{2.29} \\
\hline & 0.4 & always significant & not applicable & $8.51(0.939)$ & \\
\hline \multirow{2}{*}{8} & 0.3 & 1.05 thru 3.34 & above 3.34 & $6.33(0.918)$ & \multirow{2}{*}{1.56} \\
\hline & 0.5 & always significant & not applicable & $4.23(0.874)$ & \\
\hline \multirow[b]{2}{*}{9} & 0.3 & 1.04 thru 1.65 & above 1.65 & $3.47(0.844)$ & \multirow{2}{*}{1.23} \\
\hline & 0.7 & always significant & not applicable & $2.08(0.721)$ & \\
\hline \multirow{2}{*}{10} & 0.4 & above 1.40 & not applicable & $\begin{array}{c}\text { not applicable } \\
\text { (note 3) }\end{array}$ & \multirow{2}{*}{$\mathrm{VIF}>11$} \\
\hline & 0.41 & above 1.53 & not applicable & not applicable & \\
\hline \multirow{2}{*}{11} & 0.4 & 1.23 thru 9.09 & above 9.09 & $\mathrm{VIF}>11$ & \multirow{2}{*}{2.78} \\
\hline & 0.5 & always significant & not applicable & $7.99(0.935)$ & \\
\hline \multirow{2}{*}{12} & 0.4 & 1.14 thru 2.23 & above 2.23 & $4.59(0.884)$ & \multirow{2}{*}{1.48} \\
\hline & 0.7 & always significant & not applicable & $2.61(0.785)$ & \\
\hline \multirow{2}{*}{13} & 0.5 & above 1.93 & not applicable & not applicable & \multirow{2}{*}{$\mathrm{VIF}>11$} \\
\hline & 0.51 & above 2.27 & not applicable & not applicable & \\
\hline \multirow{2}{*}{14} & 0.5 & 1.35 thru 3.59 & above 3.59 & $6.85(0.924)$ & \multirow{2}{*}{2.04} \\
\hline & 0.7 & always significant & not applicable & $3.68(0.853)$ & \\
\hline \multirow{2}{*}{15} & 0.7 & above 4.12 & not applicable & not applicable & \multirow{2}{*}{$\mathrm{VIF}>11$} \\
\hline & 0.71 & above 6.37 & not applicable & not applicable & \\
\hline
\end{tabular}

Note 1: Each scenario was run 1001 times with VIF ranging from 1.00 to 11.00 in increments of $0.01(n=68)$. Note 2: When VIF $=11$, a standardized partial regression coefficient is equal to 0.26 and the other is 0.05 , but neither are significant $(p>0.05)$

Note 3: When $\mathrm{VIF}=11$, a standardized partial regression coefficient is equal to 0.31 and the other is 0.10 , but neither are significant $(p>0.05)$ 
According to Hair Jr. et al. (2016), VIF values of 5 or above indicate critical collinearity issues among the indicators of formative constructs, although they may also occur at lower values. Ideally, the VIF values should be close to 3 and lower.

Prior knowledge is corroborated, since as multicollinearity increases, predictors lose their interpretability in light of the relative importance (Cohen et al. , 2003, p. 421). Be that as it may, for scenarios 7 to 14, VIF values ranging from 1.08 to 3.59 will produce paths that are not significant - below recommended cutoff values. Broadly speaking, these results confirm that the issue has not received the attention it deserves by the I.B. community.

In terms of the effect of the difference $\left(r_{1 Y}-r_{2 Y}\right)$ and VIF on predictors, we note that the effect of multicollinearity does not depend solely on the IV correlations, but on the difference between the IV-DV correlations as well - in fact, the higher the difference $\left(r_{1 Y}-r_{2 Y}\right)$, the greater the effect of multicollinearity in the path, the higher correlation with the DV, and the lower path of the IV that has a lower correlation with the DV.

Figure 3 distinctly illustrates the cause that leads to suppression. When a weak DV-related IV is introduced, if the correlation with the DV is low, then the path will already be low - even in the absence of multicollinearity, if another IV (already in the model) has a strong relation with the DV. This means that the difference $\left(r_{1 Y}-r_{2 \gamma}\right)$ is large, which amplifies the effect of the VIF in the paths, so that the path of this variable becomes negative.

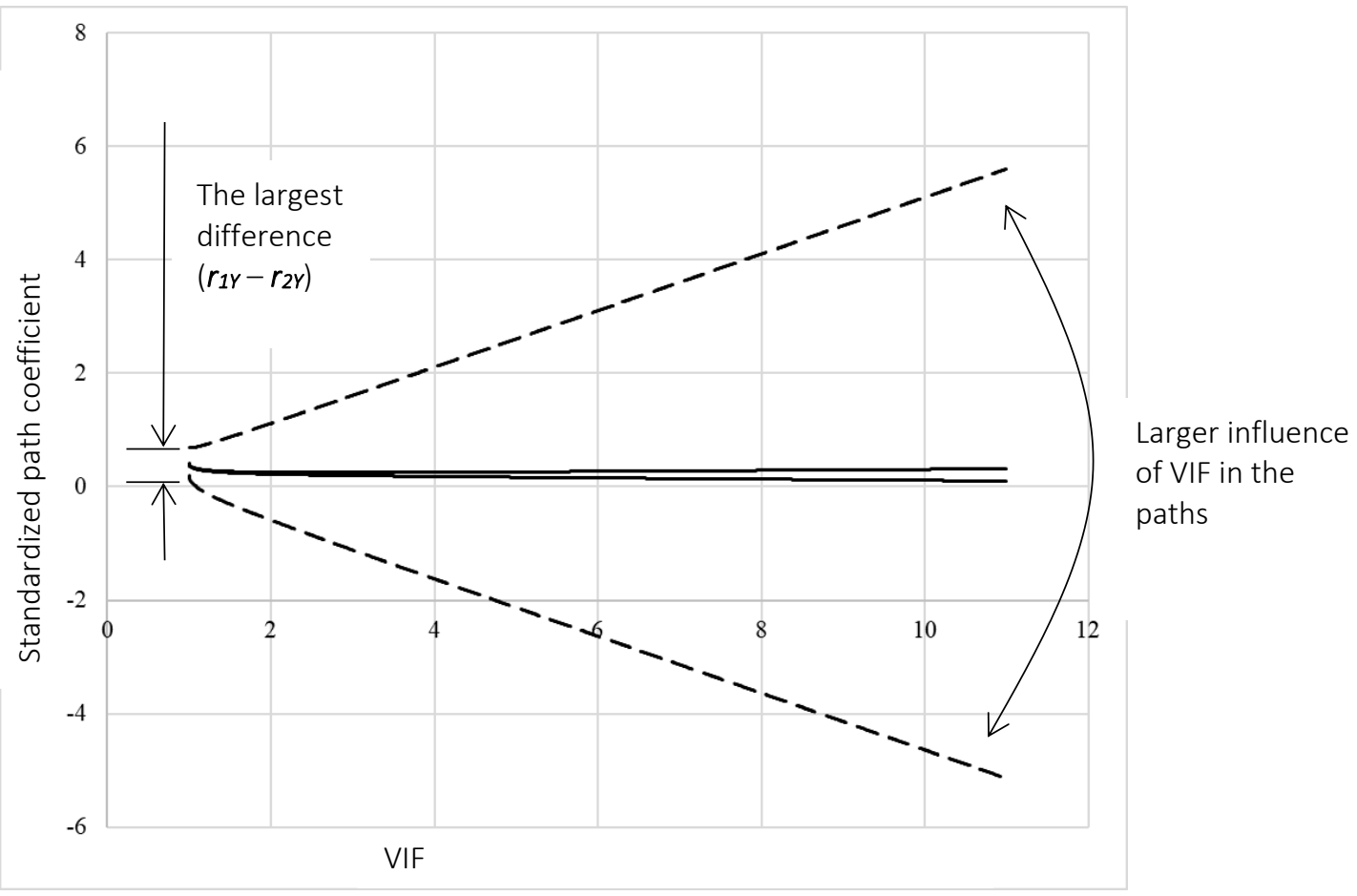

Figure 3: Effect of the difference $\left(r_{1 Y}-r_{2 \gamma}\right)$ on the VIF-path relationship Source: Research results.

Note: Graph drawn with the results of scenario $10\left(r_{1 Y}=0.41\right.$ and $\left.r_{2 Y}=0.40\right)$, which are the two central solid lines, and the results of scenario $5\left(r_{1 Y}=0.70\right.$ and $\left.r_{2 Y}=0.20\right)$, which are the two dashed lines.

The relationships among path, VIF and the difference $\left(r_{1 Y}-r_{2 Y}\right)$ are summarized in Figure 4. Here, the higher the VIF, the greater the path (in modulus).
The larger the difference between the IV - DV correlations $\left(r_{1 Y}-r_{2 Y}\right)$, the greater the influence of VIF on the path value will be. 


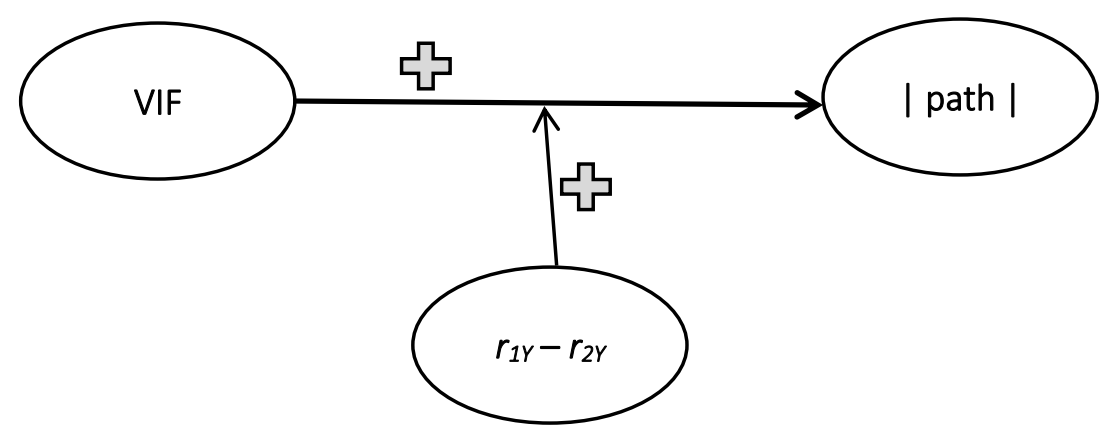

Figure 4: Path as a function of VIF and the difference between the IV-DV correlations Source: Research Results

Note: this explanation is accurate except for the region where correlation is slightly higher than zero and reduces until it reaches zero; beyond that point, the | path | will increase (as depicted in figures 2 and 3 ).

This explanation is more thorough and enlightening of the phenomenon than to simply state that the path has a negative value when $r_{1 y}<r_{2 y} \cdot r_{12}$ (Cohen et al. , 2003, p. 78) that derives from the formula in Figure 1. From a statistical point of view, the explanation is simple. However, for empirical work, when an IV that is weakly related to the DV is included, there should be strong theoretical elements to support its inclusion (Cohen et al. , 2003, p. 425).

\section{DISCUSSION OF THE IMPLICATIONS OF COLLINEARITY}

a) Importance Performance Map Analysis

Our findings corroborate Hair Jr. et al. (2010, p. 196)'s recommendation that paths be used as a guide to assess the relative importance of IVs, but only when multicollinearity is minimal. This practice should be adhered to before priority maps or performance-importance diagram (Ringle and Sarstedt, 2016) are used.

SmartPLS software (Ringle et al. , 2020) provides functionality that generates the graph depicted in Figure 5. The factorial score is shown on the vertical axis, with performance scales ranging from 0 to 100 . The horizontal axis shows the total effect (i.e. importance - or, more accurately, the direct effect).

Points in the diagram represent the IVs; the points on the right are more important, whereas those on the left are less relevant. Using a layman's term, "it would less productive to invest time in less relevant IVs, since they do not produce effects on the DV". Although the interpretation is straightforward, the relevant question is whether the leftmost IVs are there as a result of multicollinearity. In that sense, the researcher must determine if there is a moderate or severe multicollinearity; hence, when considering independent variables, we should tread carefully.

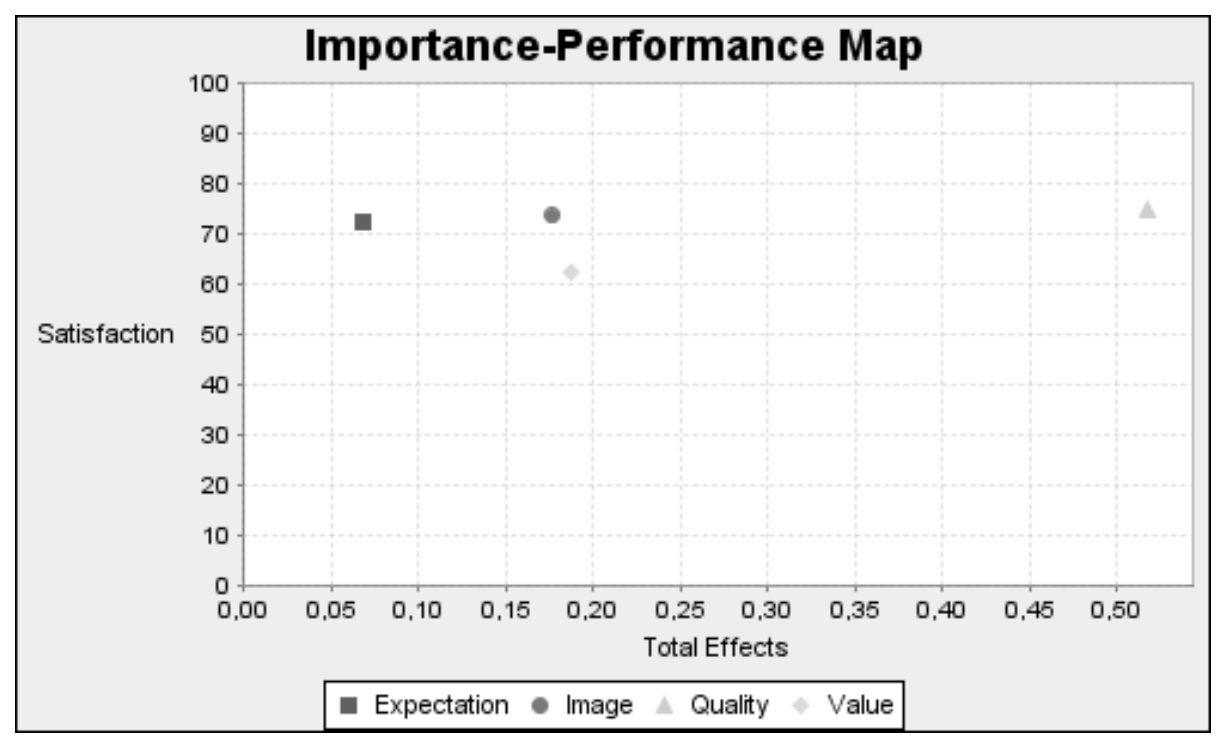

Figure 5: Example of the use of importance-performance map Source: Prepared by the authors, with data from SmartPLS v. 3 (2021) 
b) Control variables

Despite being a standard procedure when using multiple regression models, the inclusion of control variables or covariates in structural models should be used more often. They may be coded as dummy variables, or modeled as a latent formative variable (Falk and Miller, 1992; Henseler, Hubona and Ray, 2016).

The inclusion of control variables in the model must be theoretically justified (Atinc, Simmering and Kroll, 2011). Hair Jr. et al. (2010, p. 21-22) point out that including irrelevant variables may result in multicollinearity, and consequently impair the standardized regression coefficients' interpretability. The authors posit that this comment pertain specifically to multiple regression models, however, it can be argued that the same problem holds for PLSSEM models due to their mechanism's foundation on the OLS regression technique. An illustrative example from figure 2 includes an independent variable with correlation equal to 0.3 with the dependent variable (which would be a moderate effect, according to Cohen's categorization). The path coefficient may be larger than 0.3 if other multicollinear covariates, with lower correlations with respect to the dependent variables, are added to the model. In this case, how should the relation between independent and dependent variables be interpreted

Fittingly, Spector and Brannick (2011) posit that when the hypotheses are stated, it is necessary to also stipulate which variables will be controlled during the testing process. Hence, during the model specification phase (measurement model, hypotheses, and control variables), the researcher should keep the following trade-offs in mind: which variables should be included, and for what reason? Hence, if no control variable is included in the model, questions related to a possible bias that results from the omission of the variable may arise. Conversely, if the model includes too many control variables (many of which irrelevant), then the problem of multicollinearity kicks in. In the long tradition of using control variables, their inclusion receives the support of authors like Antic et al. (2011), but receives criticism from Carlson and Wu (2011). The solution is to use control variables with parsimony.

An alternative is to control the covariates during the sampling stage, by way of a segmentation designed to obtain a more homogeneous sample, in line with suggestions from Xin, Chen, Kwan, Chiu and Yim (2018).

\section{c) Common method bias (CMB)}

In SEM models, one of the causes of the overestimation of the relationships between the latent variables is the method bias, which also results in an undue increase in multicollinearity.

This issue is widely discussed by authors such as Podsakoff and Organ (1986), Podsakoff et al. (2003) and Conway and Lance (2010) when analyzing the relationships between LV and DV. Specifically, the relationships between LV and DV may be overestimated due to common sources of the data (respondent, questionnaire format, etc.). However, CMB is not limited to the relations between IV and $D V$; it can inflate the relationships between the IVs as well - that is, it could increase the multicollinearity and the effects that result from it.

Podsakoff et al. (2012) present several ways of preventing $\mathrm{CMB}$, which should be considered when preparing the data collection instrument and data field collection, including the use of different sources, or using the same source at different times, among other suggestions.

If avoiding it is not feasible, the procedures devised to detect and remove its effect are laid out by Chin et al. (2013), which is suitable for the evaluation and removal of the CMB effect in IV-DV relations. However, this method is far for being commonly agreed by researchers (to date, only 20 citations to this work were found on Scopus and Web of Science). The current stream of research uses simulations to propose adequate methods for removing the overestimation of the correlations between the IVs caused by CMB. Even though no definitive solution eliminates it, the prevention methods prescribed by Podsakoff et al. (2012) are still viable.

d) The use of path coefficients on the metaanalysis

Peterson and Brown (2005) used an empirical approach $(1,700$ beta coefficients and corresponding correlation coefficients) to derive formulas for the estimation of correlation (effect size to be used in meta-analysis); for instance: 


$$
\begin{aligned}
& r=0.98 \beta+0.05 \lambda \\
& r=\beta+0.05 \lambda \\
& r=0.99 \beta+0.04 \lambda+0.02 \eta
\end{aligned}
$$

Where:

$\lambda=1$ if $\boldsymbol{b}$ is nonnegative, and 0 if $\boldsymbol{b}$ is negative

$\eta=1$ if the average intercorrelation of the predictor was .18 or greater, and 0 if he average intercorrelation of the predictor was .17 or less

Equations 6 and 7 have no correction due to multicollinearity, and equation 8 adds a value of 0.02 when there is multicollinearity. However, as seen in figures 2 and 3 , the difference between $b$ and the correlation depends on the VIF as well as the difference between the IV-DV correlations $\left(r_{1 Y}-r_{2 Y}\right)$. Hence, Peterson and Brown's formulas tend to produce large errors when multicollinearity is higher.

\section{RECOMMENDED COMPLEMENTARY METHOD FOR THE PROBLEM CAUSED BY COLLINEARITY}

a) Grouping the multicollinear LVs into a second order latent variable

In multiple regression, for the latent variables that have high multicollinearity, the recommendation found in the literature is to eliminate the variable.

If collinearity is an issue, authors such as Hair Jr. et al. (2016); Wetzels, Odekerken-Schröder and van Oppen (2009); Wilson and Henseler (2007) posit that SEM models may be adjusted by creating a higherorder models by grouping latent variables. Cohen et al. $(2003,428)$ suggest a similar procedure and refer to this solution as principal components regression.

The logic of this strategy is as follows: if the latent variables are correlated with each other, then there could be a common cause linking them, and this would correspond to a second-order LV. However, this strategy is contingent on sound theoretical support. In other words, from a statistical point of view, replacing the collinear LV by a second-order LV may be warranted, since it does not remove any variables from the model.

However, it is a different story, from a conceptual point of view, since this decision to group latent variables would suggest that the author is conducting a theoretical revision of the underlying hypotheses, since these second-order relations are not necessarily grounded in theory. Moreover, ad hoc solutions are often questioned by other researchers, since they would give the impression that an attempt is being made to fit the model to the data.

Thus, this solution to the problem demands caution, since it demands justified theoretical foundations. In addition, in reflective-reflective and reflective-formative higher-order constructs, empirically test the hypothesized model, calculate discriminant validity, and use a validation sample.

Interpretation is still subject to problems and, when considering a second-order model, we would expect justification with regards to the effect that each independent variable has on the dependent variable. 

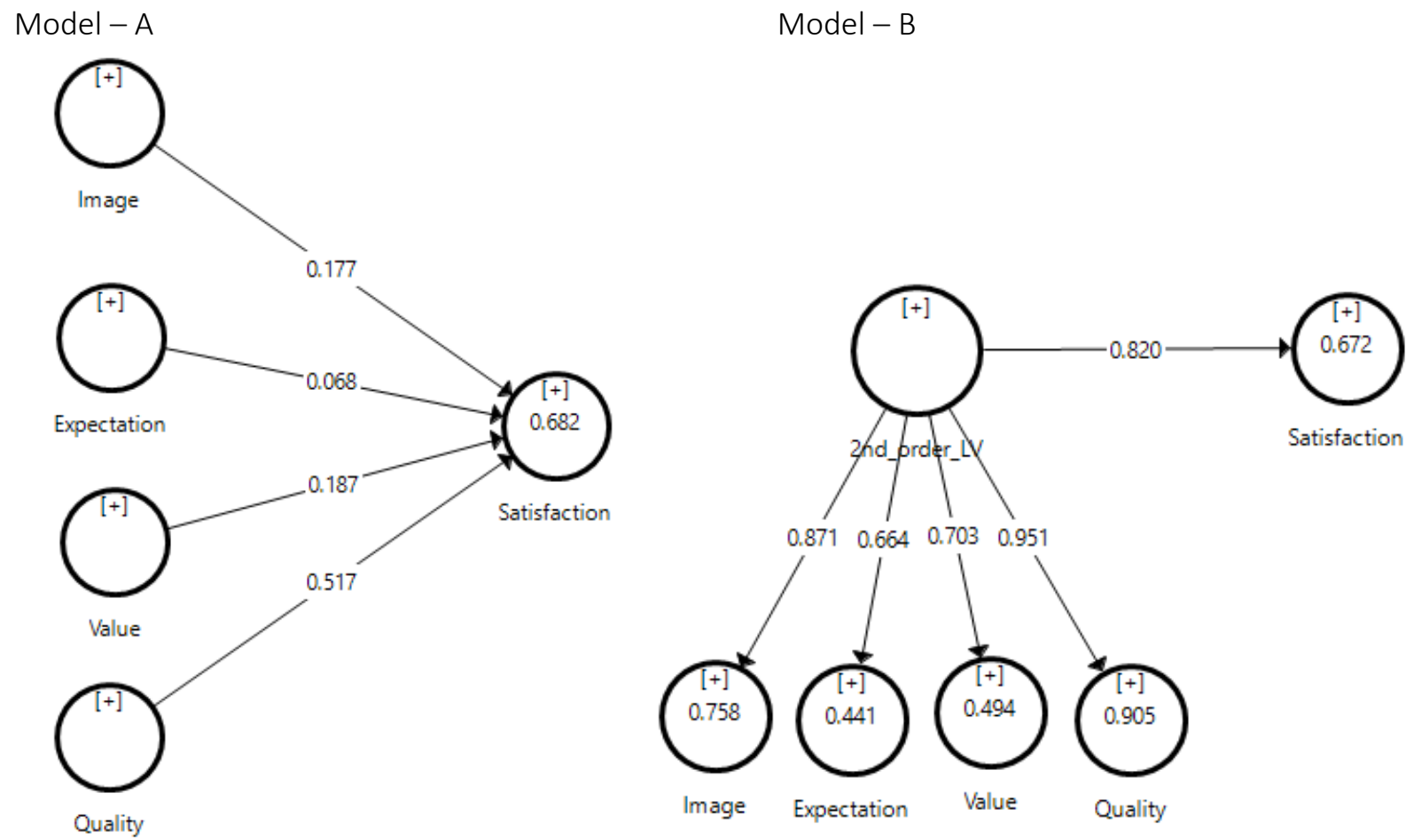

Figure 6: Multicollinear predictors versus second order latent variable Source: Prepared by the authors, with data from SmartPLS v. 3 (2021). Note: In this example, we repeat the indicators of the first order LV in their second order LV.

b) Measures of relative importance of
predictors

Multicollinearity is something that could be expected (more so than the independence between latent variables, or a null correlation). This argument is often used to justify the use of oblique rotations in Exploratory Factor Analysis (Conway and Huffcutt, 2003; Fabrigar et al. , 1999).

If multicollinearity cannot be avoided - in the sense that there is no precautionary measure to be taken when specifying a structural model -, then the recommended actions are:

(i) to detect multicollinearity, by evaluating the correlations between the variables of the model, or calculating VIF of each IV to verify if there is suppression; (ii) (ii) remedy the issue, by removing the variable or grouping them to form a second order LV.

If this conduct is not sufficient, then we turn to the initial question: does multicollinearity impair the interpretation of predictors as indicators of the relative importance of LV to explain the variance of DV? If the answer is positive, then we need to assess the relative importance of each LV in the presence of multicollinearity.

This problem may be understood by the illustration of the problem, in Figure 7. From the variance of $Y$ which is explained by the IVs $\left(R^{2}\right)$, a part is unique to each IV (regions " $a$ " and " $b$ "). But another part of the total variance is shared among the IVs (region " $\mathrm{c}$ "). 


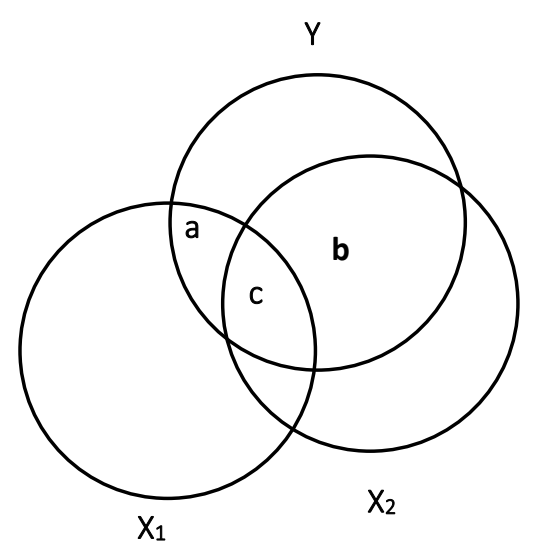

$$
\begin{aligned}
& \text { Circle area }=100 \% \text { of total variance } \\
& \begin{array}{l}
a+b+c=R^{2}=\text { variance of } Y \text { explained by } X_{1} \text { and } X_{2} \\
\begin{array}{l}
a=r_{1 Y, 2} \\
b=r_{2 Y, 1}
\end{array}
\end{array} \\
& \text { a }=\text { unique contribution of } X_{1} \text { to explain the variance of } Y \\
& b=\text { unique contribution of } X_{2} \text { to explain the variance of } Y \\
& c=\text { common contribution of } X_{1} \text { and } X_{2}
\end{aligned}
$$

Figure 7: Single and common contribution of independent variables

Source: Prepared by the authors from Cohen et al. (2003, p. 72), Hair Jr. et al. (2010, p. 198) and Nimon and Oswald (2013, p. 655).

Note: The common variance (coefficient of commonality) may be negative, indicating that one IV exerts a suppressive effect on the other (Nimon and Oswald, 2013, p. 655).

In multiple regression, this problem has been discussed since the 1960s as "relative importance of predictors" (Bansal, 2013; Hult et al. , 2018; Shackman, 2013).

According to Johnson and Lebreton (2004), simply evaluating correlations between IV and DV or path coefficients alone is a necessary (but insufficient) condition, since this procedure does not "tell the full story of the importance of the predictor" when looked in isolation, as follows:

Contribution provided by each IV to $R^{2}$, considering both its direct effect (i.e., its correlation with DV) and its effect when combined with other IVs in the regression equation. (p. 240)

These authors elaborate the concept by explaining that one of the first measures to take both aspects into account (correlation and combined effect) is the Hoffman index, which decomposes $\mathrm{R}^{2}$ (Cohen et al. , 2003, p. 83):

$$
R^{2}=b_{1} \cdot r_{1 Y}+b_{2} \cdot r_{2 Y}
$$

For PLS-SEM models, the applications of this type of evaluation were proposed by Tenenhaus et al. (2005, p. 179).

Further measures that evaluate the relative importance of the predictors are presented in Table5. 
Table 5: Measures of the relative importance of the predictor

\begin{tabular}{|c|c|}
\hline Measures & Comment \\
\hline Zero Order Correlations $\left(r_{\mathrm{ir}}\right)$ & $\begin{array}{l}\text { This measure is influenced by multicollinearity (and covariates), which } \\
\text { can be evaluated by comparing its value with the standardized } \\
\text { regression coefficient. }\end{array}$ \\
\hline $\begin{array}{l}\text { Standardized regression } \\
\text { coefficients }\left(\boldsymbol{\beta}_{\mathbf{1}}\right)\end{array}$ & $\begin{array}{l}\text { This is influenced by multicollinearity, which can be evaluated by } \\
\text { comparing its value with the zero-order correlation. }\end{array}$ \\
\hline $\begin{array}{l}\text { Utility of the predictor or } \Delta R \\
\left(R_{\text {included }}^{2}-R_{\text {excluded }}^{2}\right)\end{array}$ & $\begin{array}{l}\text { It is defined as the increase of } R^{2} \text { caused by the inclusion of IV in a model } \\
\text { that already contains other IVs. It is influenced by multicollinearity. }\end{array}$ \\
\hline $\begin{array}{l}\text { Semi-partial correlation or } \\
\text { part correlation } \\
\qquad \sqrt{\Delta \boldsymbol{R}^{2}} \\
\text { [note 2] }\end{array}$ & $\begin{array}{l}\text { It is the square root of utility. } \sqrt{R_{\text {included }}^{2}}-R_{\text {excluded }}^{2} \\
\text { Suffers influence of multicollinearity }\end{array}$ \\
\hline $\begin{array}{l}\text { Product measure }(\boldsymbol{\beta} \cdot \boldsymbol{r}) \\
\text { or Hoffman / Pratt's } \\
\text { measure }\end{array}$ & $\begin{array}{l}\text { It suffers the influence of multicollinearity and when there is } \\
\text { suppression/ its value is negative. }\end{array}$ \\
\hline Structural coefficient & $\begin{array}{l}\text { It is the correlation between the IV and the predicted values of the DV } \\
(Y) \text {, as it is a (bivariate) correlation, it does not consider the other IV. }\end{array}$ \\
\hline Communality analysis & $\begin{array}{l}\text { It basically separates the single variance explained by each IV from the } \\
\text { variance that is shared by all IVs; the sum of the single and the shared } \\
\text { variance results in the } R^{2} \text {. }\end{array}$ \\
\hline Dominance analysis & $\begin{array}{l}\text { Measure developed specifically for multicollinearity cases. Calculates } \\
\text { the mean of all } \Delta R^{2} \text { (average additional contribution), for example, with } \\
\text { three IV: } 1^{\text {st }} \Delta R^{2} \text { when } X_{1} \text { enters in isolation in the model, } 2^{\text {nd }} \Delta R^{2} \text { when } \\
X_{1} \text { enters after } X_{2}, 3^{\text {rd }} \Delta R^{2} \text { when } X_{1} \text { enters after } X_{3}, 4^{\text {th }} \Delta R^{2} \text { when } X_{1} \text { enters } \\
\text { after } X_{2} \text { and } X_{3} \text { together (Krasikova et al. , 2011). }\end{array}$ \\
\hline $\begin{array}{l}\text { Relative weights or epsilon } \\
\text { weights }\end{array}$ & $\begin{array}{l}\text { In this approach, a new set of predictors not correlated with each other } \\
\text { are created. They have maximum correlation with the original set of } \\
\text { predictors. Then both sets of predictors are used to estimate the } \\
\text { importance. } \\
\text { Developed by Johnson (2000). }\end{array}$ \\
\hline
\end{tabular}

Source: Prepared by the authors based on Johnson and Lebreton (2004), Krasikova, LeBreton and Tonidandel (2011) and Nimon and Oswald (2013).

Note 1: Some measures alone do not fit the definition of relative importance of predictors by Johnson and Lebreton (2004). In conjunction, however, they provide a clearer view of the importance of the predictor. For example, the correlation with path coefficient gives a better idea of the importance of the predictor than one of them alone.

Note 2: In SPSS, multicollinearity diagnosis other than VIF can provide part correlation and partial correlation.

In addition to VIF, SmartPLS software provides corresponds to the third option in Table 6 (Hair Jr. et Cohen's $f^{2}$ effect size measure - which basically al., 2016):

$$
f^{2}=\frac{R_{\text {included }}^{2}-R_{\text {excluded }}^{2}}{1-R_{\text {included }}^{2}}
$$


This result is interpreted per Cohen's (1988) classification for $\mathrm{f}^{2}$ effect size: 0.02 corresponds to a small effect, 0.15 moderate, and 0.35 is a large effect. A straightforward solution is to copy the standardized factor scores generated, and estimate the structural model as a multiple regression for each endogenous variable, followed by an analysis of the measures of relative importance of the predictor (Groemping, 2006, 2020, 2021; Nimon, Oswald, 2013; Nimon, Oswald and Roberts, 2020).

\section{CONCLUSIONS $^{2}$}

This study provides a relevant contribution to the field of International Business. Researchers empirically test theories with data from the field, and seek to demonstrate the effects by looking at the power and the significance of the path coefficient. However, there are issues that arise from multicollinearity, which were found to be hardly ever examined.

The research findings and the ensuing discussion present prescriptive measures to prevent, detect and remedy the effects of multicollinearity. In addition, the paper evaluates the relative importance of predictors in cases where multicollinearity is present. The continuity of this research can be done in the form of that analyzes published articles that use PLSSEM and its state-of-the-art practices.

In terms of recommendations, we posit that journal editors and reviewers be encouraged to indicate the set of prescriptive measures and best practices to authors, in order to enforce an adequate justification pertaining the choice of analytical and methodological approaches. In particular, Journal editors and reviewers should see exploratory research as a path to avoid theoretical stagnation, and in that sense the methodological measures herein presented are crucial.

The main theoretical and methodological contributions stem from the implications that were achieved through our research, by ensuring that empirical results and the outcomes of model development in International Business are reliable, replicable, and accurate. This will, in turn, produce important ramifications in terms of academic, social and managerial contributions that result from the lack of precautions, which may lead to misinformed or wrong decisions.

A question that deserves to be investigated is whether the approach of Chin et al. (2013) to detect and remedy method bias is also effective for the mitigation of multicollinearity. Specifically, the approach of these authors is only concerned with the bias that occurs in the relation IV-DV, without considering that the bias also acts in the relations among the IVs. According to Kock (2015), CMB affects the relationships between all variables and model relationships (IV-IV and IV-DV). The increase in multicollinearity due to CMB was used by Kock (2015) as a way of diagnosing its presence; specifically, when VIF is greater than 3.3, the author found evidence that $\mathrm{CMB}$ kicks in.

This study used a simulation method to support our research objectives. However, real-world models - which commonly have much more than two independent variables - may be more complex and difficult to understand.

A limitation worth mentioning is the use of positive correlations in the proposed scenarios. In order to minimize it, the various possible combinations were tested a posteriori, regardless of the possibility of actual occurrence. In all cases, the predicted behavior remained consistent with what had already been found. In some other instances, there was an inversion (path coefficients that were negative in the previous study changed and became positive).

The solution to treat the problem using a higherorder model (by merging collinear constructs in the structural model into higher order constructs) demands caution, since this strategy requires a carefully established theoretical foundations.

Importantly, though, the "explosive" influence of multicollinearity and the differences $\left(r_{1 Y}-r_{2 \gamma}\right)$ in the path coefficients persisted and were demonstrated. It is our hope that the issue of multicollinearity is better understood, and that International Business scholars adopt measures to find solutions that are sound from both the theoretical and methodological perspective.

2 Research data and additional information are available on request from the corresponding author 
121 Complementary Methods to Mitigate the Misinterpretation of Results Due to Collinearity in International

\section{REFERENCES}

Academic Journal Guide (2021), Available: https://charteredabs.org/academic-journal-guide2021/ (Accessed 20 July 2021)

Atinc, G., Simmering, M. and Kroll, M. (2011), Control Variable Use and Reporting in Macro and Micro-Management Research. Organizational Research Methods Vol. 15, 57-74. https://doi.org/10.1177/1094428110397773

Bansal, H. (2013), Investigating the measures of relative importance in marketing research. International Journal of Market Research Vol. 55, 675-695.

Beaujean, A. (2014), Latent Variable Modeling Using R: a step-by-step guide. New York: Routledge Taylor \& Francis Group.

Buckley, P.; Lessard, D. (2005), Regaining the edge for international business research, Journal of International Business Studies, Vol. 36 No. 6, pp. 595 599.

Carlson, K. and Wu, J. (2011), The Illusion of Statistical Control: Control Variable Practice in Management Research. Organizational Research Methods Vol. 15, 413-435.

Chin, W., Thatcher, J., Wright, R. and Steel, D. (2013), Controlling for common method variance in PLS analysis: the measured latent marker variable approach. In: H. Abdi, W. Chin, V. Vinzi, G. Russolillo, L. Trinchera (Eds.), New Perspectives in Partial Least Squares and Related Methods. New York: Springer. 231-239.

Cohen, J. (1988), Statistical Power Analysis for the Behavioral Sciences. 2nd ed. New York: Psychology Press.

Cohen, J., Cohen, P., West, S. and Aiken, L. (2003). Applied multiple regression/correlation analysis for the behavioral sciences. 3rd ed. New Jersey: Lawrence Erlbaum Associates, Publishers.

Conway, J. and Huffcutt, A. (2003), A Review and Evaluation of Exploratory Factor Analysis Practices in Organizational Research. Organizational Research Methods Vol. 6, 147-168.

Conway, J. and Lance, C. (2010), What reviewers should expect from authors regarding common method bias in organizational research. Journal of Business and Psychology Vol. 25, 325-334.
Diamantopoulos, A., Riefler, P. and Rith, K. (2008), Advancing formative measurement models. Journal of Business Research Vol. 61, 1203-1218.

DuBois, F.; Reeb, D. (2000) Ranking the International Business Journals. Journal of International Business Studies, Vol. 31, pp. 689-704. https://doi.org/10.1057/palgrave.jibs.8490929

Dunning, J. (2008), New directions in international-business research: a personal viewpoint, Research in Global Strategic Management, Vol. 14, 247-257.

Fabrigar, L., Wegener, D., Maccallum, R. and Strahan, E. (1999), Evaluating the use of exploratory factor analysis in psychological research. Psychological methods Vol. 4, 272.

Falk, R. and Miller, N. (1992), A Primer for Soft Modeling. Ohio: The University of Akron Press.

Grewal, R., Cote, J. and Baumgartner, H. (2004), Multicollinearity and measurement error in structural equation models: implications for theory testing. Marketing Science Vol. 23, 519-529.

Groemping, U (2006) Relative Importance for Linear Regression in R: The Package relaimpo. Journal of Statistics Software Vol. 17, 1-27.

Groemping, U. (2020), Package 'relaimpo': Relative importance of regressors in linear models ( $R$ package version 2.2-3) [software]. Available at: <https://cran.rproject.org/web/packages/relaimpo/r elaimpo.pdf>. (Accessed 20 November 2020).

Groemping, U. (2021), relaimpo: Relative Importance of Regressors. Access: $<$ http://prof.beuth-

hochschule.de/groemping/relaimpo/>

on 24/04/2021.

Gujarati, D. (2003), Basic econometrics. 4th ed. New York: McGraw-Hill/Irwin.

Hair Jr., J., Black, W., Babin, B. and Anderson, R. (2010), Multivariate Data Analysis. 7th ed. Upper Side River, NJ: Prentice Hall.

Hair Jr., J., Hult, G., Ringle, C. and Sarstedt, M. (2016), A Primer on Partial Least Squares Structural Equation Modeling (PLS-SEM). $2^{\text {nd }}$ ed. Thousand Oaks, CA: Sage Publications, Inc. 
Henseler, J., Hubona, G., Ray, P. (2016), Using PLS Path Modeling in New Technology Research: Updated Guidelines. Industrial Management \& Data Systems Vol. 116, 2-20.

Henseler, J., Ringle, C. and Sinkovics, R. (2009), The use of partial least squares path modeling in International Business. Advances in International Business Vol. 20, 277-319.

Hult, G.; Hair Jr., J.; Proksch, D.; Sarstedt, M.; Pinkwart, A. and Ringle, C. (2018), Addressing Endogeneity in International Business Applications of Partial Least Squares Structural Equation Modeling, Journal of International Business, Vol. 26, No. 3, 1-21

Johnson, J. (2000), A heuristic method for estimating the relative weight of predictor variables in multiple regression. Multivariate Behavioral Research Vol. 35, 1-19. DOI: 10.1207/S15327906MBR3501_1

Johnson, J. and Lebreton, J. (2004), History and use of relative importance indices in organizational research. Organizational Research Methods Vol. 7, 238-257.

Krasikova, D.; LeBreton, J.; Tonidandel, S. (2011). Estimating the Relative Importance of Variables in Multiple Regression Models. In International Review of Industrial and Organizational Psychology Vol. 26, 119-141, John Wiley and Sons Ltd. https://doi.org/10.1002/9781119992592.ch4

Kennedy, P. (1998), A guide to econometrics. 4th ed. Malden: Blackwell Publishing Ltd.

Kock, N. (2015) Common method bias in PLS-SEM: A full collinearity assessment approach. International Journal of e-Collaboration Vol. 11, 1-10.

Nimon, K. and Oswald, F. (2013), Understanding the Results of Multiple Linear Regression: Beyond Standardized Regression Coefficients. Organizational Research Methods Vol. 16, 650-674.

Nimon, K., Oswald, F. and Roberts, J. (2020), Package 'yhat': Interpreting Regression Effects ( $\mathrm{R}$ package version 2.0-0) [software] Available: https://cran.rproject.org/web/packages/yhat/yhat.p df (Accessed 20 November 2020).

Peterson, R. and Brown, S. (2005), On the use of beta coefficients in meta-analysis. Journal of Applied Psychology Vol. 90, 175-181. DOI: 10.1037/00219010.90.1.175
Podsakoff, P., Mackenzie, S., Lee, J.-Y. and Podsakoff, N. (2003), Common method biases in behavioral research: a critical review of the literature and recommended remedies. The Journal of Applied Psychology, Vol. 88, 879-903.

Podsakoff, P., Mackenzie, S. and Podsakoff, N. (2012), Sources of method bias in social science research and recommendations on how to control it. Annual Review of Psychology, Vol. 63, 539-69.

Podsakoff, P. and Organ, D. (1986), Self-reports in organizational research: problems and prospects. Journal of Management, Vol. 12, 531-544.

Richter, N., Sinkovics, R., Ringle, C., and Schlägel, C. (2016) A critical look at the use of SEM in international business research, International Business Review, Vol. 33 No. 3, 376-404. DOI 10.1108/IMR-04-2014-0148.

Ringle, C. and Sarstedt, M. (2020), Gain More Insight from Your PLS-SEM Results: The ImportancePerformance Map Analysis (October 31, 2015). Industrial Management \& Data Systems, Vol. 116, No. 9, 1865-1886, 2016, Available at SSRN: https://ssrn.com/abstract=2984821 (Accessed 20 July 2021)

Ringle, C., Wende, S. and Becker, J.-M. (2020), Software SmartPLS 3. Boenningstedt: SmartPLS GmbH. Access: http://www.smartpls.com (Accessed 20 November 2020).

Seno-Alday, S. (2010), International business thought: a 50 year footprint, Journal of International Management, Vol. 16 No. 1, pp. 16-31.

Shackman, J. (2013), The Use of Partial Least Squares Path Modeling and Generalized Structured Component Analysis in International Business Research: A Literature Review, International Journal of Management, Vol. 30 No. 3 Part 1

SmartPLS v. 3 (2021), European Customer Satisfaction Index (ECSI) example. Data and project available at: https://www.smartpls.com/documentation/sampleprojects/ecsi (Accessed 20 July 2021)

Spector, P. and Brannick, M. (2011), Methodological urban legends: The misuse of statistical control variables. Organizational Research Methods Vol. 14, 287-305. https://doi.org/10.1177/1094428110369842. 
123 Complementary Methods to Mitigate the Misinterpretation of Results Due to Collinearity in International

Tenenhaus, M., Esposito Vinzi, V., Chatelin, Y. and Lauro, C. (2005), PLS path modeling. Computational Statistics \& Data Analysis Vol. 48, 159-205.

Tsui, A. (2007), From homogenization to pluralism: international management research in the academy and beyond, Academy of Management Journal, Vol. 50 No. 6, 1353-1364.

Wetzels, M., Odekerken-Schröder, G. and van Oppen, C. (2009), Using PLS path modeling for assessing hierarchical construct models: guidelines and empirical illustration. MIS Quarterly Vol. 33, 177195.

White, G., Guldiken, O., Hemphill, T., He, W., Khoobdeh, M. (2016), Trends in International Strategic Management Research from 2000 to 2013:
Text Mining and Bibliometric Analyses, Management International Review, Springer, vol. 56(1), 35-65, February, DOI: 10.1007/s11575-015-0260-9

Wilson, B. and Henseler, J. (2007), Modeling reflective higher-order constructs using three approaches with PLS path modeling: A Monte Carlo comparison. Australian and New Zealand Marketing Academy (ANZMAC) Conference. Proceedings... 791800. Available: http://doc.utwente.nl/91758/1/BWilson 2.pdf .

Xin, J., Chen, S., Kwan, H., Chiu, R. and Yim, F. (2018), Work-Family Spillover and Crossover Effects of Sexual Harassment: The Moderating Role of WorkHome Segmentation Preference. Journal of Business Ethics Vol. 147, 619-629. https://doi.org/10.1007/s10551-015-2966-9 


\section{Attachment}

Articles analyzed

Diallo, M.; Diop-Sall, F.; Djelassi, S. and GodefroitWinkel, D. (2018), How Shopping Mall Service Quality Affects Customer Loyalty Across Developing Countries: The Moderation of the Cultural Context, Journal of International Business, Vol. 26 No. 4, 69-84

Ferreras-Mendez, J.; Fernandez-Mesa, A. and Alegre, J. (2019), Export Performance in SMEs: The Importance of External Knowledge Search Strategies and Absorptive Capacity, Management International Review, Vol. 59, 413-437

Fey, C.; Morgulis-Yakushev, S.; Park, H. and Björkman, I. (2009), Opening the black box of the relationship between HRM practices and firm performance: A comparison of MNE subsidiaries in the USA, Finland, and Russia, Journal of International Business Studies, Vol. 40, 690-712.

Gabel-Shemueli, R.; Westman, M.; Chen, S. and Bahamonde, D. (2019), Cross Cultural \& Strategic Management, Vol. 26, No. 1, 46-66

Jean, R.; Sinkovics, R. and Zagelmeyer, S. (2018), Antecedents and Innovation Performance Implications of MNC Political Ties in the Chinese Automotive Supply Chain, Management International Review, Vol. 58, 995 - 1026

Jean, R. and Tan. D. (2019), The Effect of Institutional Capabilities on E-Business Firms' International Performance, Management International Review, Vol. 59, 593-616

Khan, Z.; Shenkar, O. and Lew, Y. (2015), Knowledge transfer from international joint ventures to local suppliers in a developing economy, Journal of International Business Studies, Vol. 46, 656-675

Kock, F.; Josiassen, A. and Assaf, A. (2019), Toward a Universal Account of Country-Induced Predispositions: Integrative Framework and Measurement of Country-of-Origin Images and Country Emotions, Journal of International Business, Vol. 27, No. 3, 43-59
Lam, S.; Ahearne, M. and Schillewaert, N. (2012), A multinational examination of the symbolicinstrumental framework of consumer-brand identification, Journal of International Business Studies, Vol. 43, 306-331

Lee, H. and Griffith, D. (2019), The Balancing of Country-Based Interaction Orientation and Marketing Strategy Implementation Adaptation/ Standardization for Profit Growth in Multinational Corporations, Journal of International Business, Vol. 27, No. 2, 22-37

Lee, K.; Yang, G. and Graham, J. (2006), Tension and trust in international business negotiations: American executives negotiating with Chinese executives, Journal of International Business Studies, Vol. 37, 623-641

Lew, Y.; Sinkovics, R.; Yamin, M. and Khan, Z. (2016), Trans-specialization understanding in international technology alliances: The influence of cultural distance, Journal of International Business Studies, Vol. 47, 577-594

Mohammad, J.; Quoquab, F.; Makhbul, Z. and Ramayah, T. (2016), Bridging the gap between justice and citizenship behavior in Asian culture, Cross Cultural \& Strategic Management, Vol. 23, No. 4, 633656

Money, B. and Graham, J. (1999), Salesperson Performance, Pay, and Job Satisfaction: Tests of a Model Using Data Collected in the United States and Japan, Journal of International Business Studies, Vol. 30, No. 1, 149-172

Morgeson III, F.; Sharma, P. and Hult, G. (2015), Cross-National Differences in Consumer Satisfaction: Mobile Services in Emerging and Developed Markets, Journal of International Business, Vol. 23, No. 2, 1-24

Obadia, C.; Bello, D. and Gilliland, D. (2015), Effect of exporter's incentives on foreign distributor's role performance, Journal of International Business Studies Vol. 46, 960-983

Pinho, J. and Thompson, D. (2016), Institutionaldriven dimensions and the capacity to start a business: A preliminary study based on two countries, International Business Review, Vol. 34, No. 6, 787-813 
125 Complementary Methods to Mitigate the Misinterpretation of Results Due to Collinearity in International

Richter, N. (2007), Intra-Regional Sales and the Internationalization and Performance Relationship, Rugman, A.M. (Ed.) Regional Aspects of Multinationality and Performance, Research in Global Strategic Management, Vol. 13, Emerald Group Publishing Limited, Bingley, 359-381. https://doi.org/10.1016/S1064-4857(07)13015-1

Schotter, A. and Beamish, P. (2013), The hassle factor: An explanation for managerial location shunning, Journal of International Business Studies, Vol. 44, 521-544
Shi, L.; White, J.; Zou, S. and Cavusgil, S. (2010), Global account management strategies: Drivers and outcomes, Journal of International Business Studies, Vol. 41, 620-638

Stewart Jr.; W; May, R. and Ledgerwoord, D. (2015), Do You Know What I Know? Intent to Share Knowledge in the US and Ukraine, Management International Review, Vol. 55, 737-773

Venaik, S.; Midgley, D. and Devinney, T. (2005), Dual paths to performance: the impact of global pressures on MNC subsidiary conduct and performance. Journal of International Business Studies, Vol. 36, 655-675

Diogenes de Souza Bido - Universidade Presbiteriana Mackenzie - M, São Paulo, (Brasil). E-mail: diogenesbido@yahoo.com.br Orcid id: https://orcid.org/0000-0002-8525-5218

Antonio Carlos de Oliveira Barroso - Instituto de Pesquisas Energéticas e Nucleares - IPEN, São Paulo, (Brasil). E-mail: acobarroso@gmail.com

Eric David Cohen - Universidade Estadual de Campinas - UNICAMP, Campinas, São Paulo, (Brasil). E-mail: ericdcohen@gmail.com Orcid id: https://orcid.org/0000-0003-0994-1731 


\title{
MÉTODOS COMPLEMENTARES DE RESOLUÇÃO DA INTERPRETAÇÃO INCORRETA DO EFEITO DA COLINEARIDADE NAS PESQUISAS DE NEGÓCIOS INTERNACIONAIS
}

\author{
Diogenes de Souza Bido, Antonio Carlos de Oliveira Barroso \& Eric David Cohen \\ Universidade Presbiteriana Mackenzie - M, São Paulo, (Brasil) \\ Instituto de Pesquisas Energéticas e Nucleares - IPEN, São Paulo, (Brasil) \\ Universidade Estadual de Campinas - UNICAMP, Campinas, São Paulo, (Brasil)
}

\section{DETALHES DO ARTIGO}

\section{Histórico do Artigo:}

Recebido em: 19 de janeiro de 2021

Aceito: 03 de julho de 2021

Disponível online: 25 de outubro de 2021

\section{Sistema de revisão "Double blind review" \\ Editor Científico \\ Ilan Avrichir}

\section{Palavras-chaves:}

Modelagem de equações estruturais

Multicolinearidade

Negócios internacionais

\section{RESUMO}

Objetivos do estudo: evidenciar lacuna metodológica nos trabalhos empíricos da área de Negócios Internacionais que utilizam modelos estruturais, e prescrever métodos complementares para mitigar o problema da colinearidade.

Método: empregou-se uma simulação para evidenciar os efeitos da colinearidade em relação à importância e significância dos preditores, e apresentados métodos voltados ao controle do efeito indesejado da colinearidade.

Principais resultados: proposição de métodos complementares que incluem o agrupamento das variáveis latentes que apresentam multicolinearidade em modelos de segunda ordem, e a utilização da medida de importância relativa dos preditores.

Contribuições teóricas e metodológicas: a contribuição se dá frente à prescricao de técnicas oferecidas à comunidade acadêmica para a realização de pesquisas empíricas, que foram alcançadas pelo presente estudo.

Relevância e originalidade: a partir das lacunas apontadas na produção cientifica recente do campo de conhecimento dos Negócios Internacionais, são elencadas medidas para mitigar a questao da colinearidade.

Contribuições sociais e para a gestão: dentre as principais implicações gerenciais e sociais alcançadas por meio dos achados aqui apresentados, promove-se o desenvolvimento de pesquisas empíricas robustas, relevantes e confiáveis. 


\title{
MÉTODOS COMPLEMENTARIOS PARA RESOLVER MALA INTERPRETACIÓN DEBIDA A LOS EFECTOS DE LA COLINEALIDAD EN LA INVESTIGACIÓN DE NEGOCIOS INTERNACIONALES.
}

\author{
Diogenes de Souza Bido, Antonio Carlos de Oliveira Barroso \& Eric David Cohen \\ Universidade Presbiteriana Mackenzie - M, São Paulo, (Brasil) \\ Instituto de Pesquisas Energéticas e Nucleares - IPEN, São Paulo, (Brasil) \\ Universidade Estadual de Campinas - UNICAMP, Campinas, São Paulo, (Brasil)
}

\begin{tabular}{l} 
DETALLES DEL ARTÍCULO \\
\hline Historia del Artículo: \\
Recibido: 19 de enero de 2021 \\
Aceptado: 03 de julio de 2021 \\
Disponible en línea: 25 de octubre 2021 \\
Double Blind Review System \\
Editor Científico \\
Ilan Avrichir
\end{tabular}

\section{Palabras-clave:}

Modelado de ecuaciones estructurales

Multicolinealidad

Negocios Internacionales

\section{RESUMEN}

Objetivos del estudio: demostrar la brecha metodológica en los trabajos empíricos del área de Negocios Internacionales que utilizan modelos estructurales, y prescribir métodos complementarios para mitigar el problema de la colinealidad.

Método: se utilizó una simulación para evidenciar los efectos de la colinealidad para la importancia y significación de los predictores, y se desarrolló acciones dirigidas a controlar el efecto no deseado de la colinealidad.

Resultados principales: proposición de métodos complementarios que incluyen la agrupación de variables latentes que presentan multicolinealidad en modelos de segunda orden, y el uso de la medida de importancia relativa de los predictores.

Aportes teóricos y metodológicos: el aporte se basa en los métodos complementarios ofrecidos a la comunidad académica para realizar investigación empírica, lo cual se logró a través de los resultados de este estudio.

Relevancia y originalidad: a partir de las brechas señaladas en la reciente producción científica del campo del conocimiento de Negocios Internacionales, se enumeran medidas para mitigar el problema de la colinealidad.

Contribuciones sociales y gestión: entre las principales implicaciones gerenciales y sociales logradas a través de los hallazgos del presente estudio, se promueve el desarrollo de investigaciones empíricas robustas, relevantes y confiables.

\section{How to cite this article:}

Bido, D. de S., Barroso, A. C. de O., \& Cohen, E. D. (2022). Complementary Methods to Mitigate the Misinterpretation of Results Due to Collinearity in International Business Research. Internext, 17(1), 105127. https://doi.org/10.18568/internext.v17i1.681 